UDC 821.161.2-3: 82.0

DOI https://doi.org/10.32782/tps2663-4880/2021.17-2.30

\title{
ESSAYS AS THE SUBJECT OF STUDY OF MODERN LITERATURE STUDIES
}

\section{ЕСЕЙ ЯК ПРЕДМЕТ ВИВЧЕННЯ СУЧАСНОГО ЛІТЕРАТУРОЗНАВСТВА}

\author{
Hanchenko A.Yu., \\ orcid.org/0000-0002-4271-5368 \\ Applicant at the Department of Ukrainian Literature \\ Odesa I.I. Mechnikov National University
}

\begin{abstract}
The article is devoted to the scientific understanding of the essay as a literary work in view of the traditions of a modern literary criticism. The emergence of the essay genre caused in Ukrainian culture a decisive and rapid re-emphasis of values, a change in the basic ideas about the very essence of writing and its relevance to society. In the period of change of literary traditions, styles, forms, first of all, it was a question of the statement of self-sufficiency of the essay as a genre. A philosophical work by nature, it becomes a traditional work of fiction at the beginning of the XXIst century, absorbing traditions and acquiring new features. In the presented article, based on some theoretical works of modern researchers, aspects of the origin and development of the essay genre as a literary work are clarified. The essay is considered from a literary point of view, first of all, from the standpoint of genre specificity, content and form, the author and the recipient. The article presents various tendencies and directions of literary-critical comprehension of the raised question. These are literary-critical achievements presented in the works of G. Lukach, K. Osadcha, K. Silman, T. Shevchenko, S. Shebelist, O. Hook, M. Balaklitsky, G. Klochek, etc. Among the issues raised in the article and discussed by modern literary critics is the role and place of essays as an authoritative literary genre, which is the basis for the creation of "great" literature that represents modern Ukrainian literature in particular. Aspects of attention of literary criticism of the postmodern era are outlined: style, genre specificity, conformity of form and content, establishment of aesthetic values. The phenomenon of essays as a question of rethinking the genre-thematic paradigm of modern essays is analyzed. The article considers and comprehends the specifics of the meta-genre nature of essay writing and the origin, place of discursive practices that are implemented in the context of creating and implementing the meanings of the work.
\end{abstract}

Key words: literary studies, stylistic syncretism, essays, essayistic, meta-genre, postmodernism.

Статтю присвячено науковому осмисленню есею як літературного твору з огляду на традиції сучасного літературознавства. Поява жанру есею спричинила в українській культурі рішучу та швидку переакцентацію вартостей, зміну базових уявлень про саму сутність письменства і його стосунок до соціуму. У період зміни літературних традицій, стилів, форм передусім йшлося про утвердження самодостатності есею як жанру. Філософфський за природою твір стає традиційним для художньої літератури твором на початку XXI ст., вбираючи традиції і набуваючи нових ознак. У презентованій статті на матеріалі окремих теоретичних праць сучасних дослідників з'ясовуються аспекти походження та розвитку жанру есею як літературного твору. Есей розглядається з літературознавчого погляду, насамперед із позицій жанрової специфіки, змісту і форми, автора та реципієнта. Стаття представляє різні тенденції й напрями літературно-критичного осмислення порушеного питання. Йдеться про літературно-критичні здобутки, представлені у працях Г. Лукача, К. Осадчої, К. Сільман, Т. Шевченко, С. Шебеліста, О. Гук, М. Балаклицького, Г. Клочека тощо. Серед проблем, порушених у статті та дискутованих сучасними літературознавцями, - роль і місце есеїстики як авторитетного літературного жанру, що є засадою для створення «великої» літератури, котра репрезентує українську літературу сучасності зокрема. Окреслено аспекти уваги літературознавства постмодерністської доби: стиль, жанрова специфіка, відповідність форми та змісту, усталення естетичних вартостей. Проаналізовано явище есею як питання переосмислення жанрово-тематичної парадигми сучасної есеїстики. У статті розглянуто та осмислено специфіку метажанрової природи есеїстичного письма, походження і місце дискурсивних практик, що реалізуються у контексті створення та впровадження смислів твору.

Ключові слова: літературознавство, стильовий синкретизм, есей, есеїстика, метажанр, постмодернізм.

Statement of the problem in general and its connection with scientific tasks. In recent decades, the question of the role and place of essays among a large number of literary genres remains relevant. The nature of the origin and genre specifics of the chosen form represent a variety of topics and issues, the systems of conflicts and their reflection in the context of perception, which is a kind of author's analysis and reading experience, communication with reality, reflection on current events.

Modern Ukrainian literary space signals the restructuring of the form and content of the work. The narrative model, which varies depending on the role of the reader and the author in the text, as well as outside it, actualizes not only the intellectual potential of the recipient, but also his ability to communicate with the meanings of the work in the process of reading and understanding. Consolidating the tendencies of a previous experience, representing them in the modern interpretation, the essay is an example of a work (in the sense of genre) multifaceted and debatable, covering the contexts of the humanities tradition, difficult to demarcate into certain boundaries, characteristics, periods.

Due to the fact that literary critics cannot inscribe a work in the canon and comprehend the definitions 
of the genre, which is characterized by variability of forms and content, there are different literary interpretations of this phenomenon. The main task of the study is to understand the origin and development of the essay in the world and domestic literary tradition, because its "vagueness" is primarily associated with the already mentioned "blurred boundaries" and "impossibility of their delineation."

Analysis of recent research and publications. Research on the origin, place and role of modern essays is very diverse: a large number of works are devoted to the theoretical understanding of this problem. The ideas about the origin of the essay were realized in the works of S. Shebelist, M. Balaklitsky, T. Shevchenko, T. Meiserskaya, Y. Nesterenko, M. Hnatiuk, K. Silman, T. Tselyukh, O. Hook, N. Myroshkina, G. Klochek. The conceptualization of the term develops in the researches of T. Levchuk, O. Khoma, V. Skuratovsky. Articles and publications are devoted to the theoretical understanding of the origin of the essay as a literary work, the object of scientific delineation in the literary tradition of today and the attempt to generalize the results of research.

Presenting the main material. The first representation of the essay as a genre can be seen in the publication of a three-volume book by a French philosopher and Renaissance writer Michel Montaigne "Les Essais" (translated from French "Samples"). The author, in the form of an essayistmoralist, attempted to write the work under the slogan "Who am I?", personifying human thought, devoid of dogmatism and scholasticism, full of categories of fearlessness and criticism.

As for the uncharacteristic for the Renaissance manner of presentation, the work was a syncretic formation of various genres: from philosophical explorations, poems in prose, to everyday life and critical essays. In the language of the original, Montaigne's work is called "Essays", which from the very beginning is open to external influences. It should be noted that it is in such attempts at authorial writing that the so-called "metamorphic genre" (T. Levchuk) is formed, which from the very beginning finds itself outside the canons of literary creativity.

A collection of the first essays of the English tradition, presented by Francis Bacon's Essays, in which the author emphasized the direct origin of an essay on the ancient tradition, namely the works of Aristotle, Plato's dialogues and the recitations of Lucian, John Milton "The Tenure of Service of Kings and Magistrates". However, the main development of essays and essayistic thought dates back to modern times.
Certainly, the stylistic syncretism, change of writing style and free character in the choice of themes allowed the artists of that period to implement in the works the product of assimilation of various arts, philosophical and spiritual practices, which transformed not only the manner of writing literary works, the recipient. It is obvious that such conditions have been favorable for the development of essay writing.

As an independent genre in the field of Ukrainian literature, the essay began to function only in the twentieth century in the works of I. Franko, P. Kulish, V. Vynnychenko on the basis of the Lviv magazine "Visnyk" edited by D. Dontsov. A little later, he appeared in the works of the sixties, known in the magazines "October", "Dnipro", the newspaper "Literary Ukraine". The genre flourished in the 1990s in the works of Yu. Andrukhovych, O. Zabuzhko, T. Prokhasko, and M. Ryabchuk.

Given the literary thought, the essay is a representative of an objective reality, a subject of reflection and expression of aesthetic categories, which, due to the high level of intellectual and spiritual content, reveals to the reader "experience" with different connotations, filling the space with broad cultural context and art. images. This multi-vector specificity of the genre, perhaps, contributes to the formation of individual reader's opinion, leveling stereotypes and acquired experience, which often correlates with the subject comprehension and aesthetic mastery of the world. It should be noted that this understanding allows us to consider essays in the context of social-communicative approach, discursive practices, removing essays from the category of unusual works of Ukrainian literature.

Mostly, the German theorists began work on a literary-critical understanding of the essay as a genre. In 1910 G. Lukach wrote the text "On the Nature and Form of the Essay: Letter to Leo Popper ", where he put forward the following understanding of the genre: якщо поезія, себто сфера літератури вигадки, породжена одвічним людським прагненням зупинити мить життя в усій чуттєвій повноті, то така ж фундаментальна потреба в поглибленому аналізі безпосереднього досвіду задовольняється жанром есею [9]. G. Lukach notes that the essay is a universal genre, the main purpose of which is an in-depth analysis of human experience gained in the process of understanding objective reality.

Ukrainian modern essays began to develop more actively after the twentieth century in the works of K. Silman, O. Hook, Y. Nesterenko, S. Shebelista, T. Tseliukh, O. Zelik, N. Myroshkina, O. Slyvynsky. 
In the works of these researchers, we should note, the problems of poetics of the genre, the subject of the essay, as well as its discursive properties and aesthetic functions, which are implemented in the communicative strategies of the author.

S. Shebelist in work "Theoretical Aspects of the Essay Genre" (2007) notes "виникнувши в момент переходу від середньовічного мислення до науки нового часу, ией жанр відображає нову ситуацію пізнання: ізольоване "Я» перед обличчям світу, про який нічого невідомо напевно. Есей щоразу починає заново, пропонує особистий досвід, а не професійні знання» [9].

Indeed, the author represents the idea that the essay genre combines in its form and content a situation of experience and cognition that meets the intellectual and spiritual needs of the recipient, filling the category of "unknown", "isolated", offering solutions by empiricism rather than a scholastic, gradual application of already known concepts acquired in the process of establishing causal relationships.

Researcher K. Silman in the work "Essay as a Genre at the Intersection of Literature and Journalism" (2019) emphasizes the impermanence of the features of the essay as a genre, which is quite justified, classifying them as immanent: «Есей $я \kappa$ небелетристичний жанр, якому властиві як художні, так $і$ публіцистичні риси $і$ який вирізнясться вільною композицією, яскравим вираженням авторської індивідуальності та актуальністю обговорюваної теми. Залежно від сфери функиіонування есею, він може змінювати набір домінантних $i$ периферійних ознак та набувати нових» [7, с. 139].

The author notes that despite the large number of differential features of the essay, their presence is not only volatile but also variable, which corresponds to the given context, the dominance of which will change depending on the author's strategy and reader's perception. However, the researcher's remarks about the systematization and informativeness of the studied phenomenon are quite accurate. According to the author, the essay increasingly acquires the categories of integrity, coherence, articulation, linearity, informativeness, prospecting / retrospection and completeness from the standpoint of their representation.

O. Hook in the article "Formation of the Identity of the Essay Genre: Methodological Aspect" analyzes the origin of the essay as one of the debatable phenomena and genres of modern genealogy, noting that the ancestor of the genre is ancient literature and philosophy, but the most significant features of the genre traditions and expand the concept of essays in scientific systems. Also interesting is the idea that the essay is formed in the stream of genres "with increased reflection and author's assessment", which allows us to reflect on the above ideas about the genre's compliance with the needs of the time.

The author decisively notes: «на відміну від жанрової домінанти роману, що є творінням замкнутої в собі, вигаданої реальності, есеїзачія долає иі рамки художньої умовності, ліквідує романізацію реальності, переводить ї̈ у нескінченний потік текстуальності» [4, с. 37]. This means that writers oppose fiction, and represent in their works the space of modernity, that is, the objective reality of the recipient himself. In other words, the systematicity and perfection of the work is supported by the authority of the author himself, but is questioned by the reader's interpretation.

T. Shevchenko in the monograph "Essays of Ukrainian Writers as a Phenomenon of Literature of the late XXth - the beginning of the XXIst century" (2019) theoretically comprehends the nature of the essay and its place among the various genres of Ukrainian literature. The researcher chiefly outlines the essay as an artistic-discursive practice in the modern literary process. Analyzing in the monograph the work of M. Markovsky, N. Myroshkina, A. Dmitrovsky and many other researchers, the author notes: «головні ознаки жанру (в традииійному розумінні) такі: конвенційні відносини між автором та адресатом; спадковість сприйняття; повторювання ознак; історична рухомість; зв'язок з епохою» [11, с. 29]. The researcher emphasizes the detailed analysis of the form of "ensemble association of writers' essays" in the context of the topological turn in culture and the literary process in general.

According to the researcher $Y u$. Osadcha in the work "Essay and Novelistic Writing as a Way to" Think "Literature" (2006) it is noteworthy that "есеїстичне письмо, як притаманний насамперед его-белетристииі спосіб побудови авторського дискурсу має безпосередній генетичний зв'язок есеїстичною літературою та перейняло від неї ряд особливостей. Проте цей тип письма не обмежується есеєм як жанровою формою та иілком може бути реалізований в інших формах» [6, с. 30] The researcher substantiates the opinion that essay writing is not limited to only one form and is characterized by their invariance. This represents the studied phenomenon as multifaceted, unstable and dependent on the author's intention.

Addressing the issue of self-identification, researcher G. Shvets in the work "Essays by Vasyl 
Barka: GenreSpecificsandIssues"(2006)emphasizes: «головним для есеїстики $є$ спрямованість на самоствердження, самоідентифікацію письменника» [8, с. 19] Probably, this happens in the process of creating an essay, reproducing its space and time, the system of characters and a set of conflicts.

However, the question of self-identification in the work is quite debatable, because referring to the opinion of R. Bart and his concept of "author's death", we can see that the author's death begins where the work ends and the reader's interpretation is born. The researcher also emphasizes: «сьогодні есеїстика - один із лідерів літературного nроиесу», which is fullyjustified by the wild popularity of the genre among writers of metamodernism.

We find similar ideas in the works of $O$. Hnatiuk in the work "Essay is a Way of Life, where Culture is Foundation" (2018) addresses the genre nature of the essay and the problems of its origin. The researcher notes: «Есей - ие не художня проза, не публіцистична стаття, не журналістський нарис, не ескіз, не репортаж, не фейлетон, не спогад $i$ не наукова розвідка (хоч елементом есею, себто прикладом чогось, унаочненням явища, вкрапленням може бути і спогад, $і$ погляд репортажсиста, i публічистика) 》 [2]. Before the researcher, the essay appears as something more than just a literary work: «Есей - ие спосіб життя, вякомуфундаментомєкультура.Есей-иеактивний пошук, себто рефлексія або запис індивідуального пошуку правди, намагань ї̈ осягнути, прагнення зрозуміти себе і світ. Слово “пошук”, мабуть, заслуговує на основне місие. Есей - ие завжди діалог з кимось / чимось (наприклад, традииісю), не монолог. Есей - це неповторність стилю, думки, світобачення. Есей - ие синкретизм, себто поєднання художньості й документалізму, історизму та автобіографізму з філософськими амбіиіями» [2].

The author notes that the essay is a constant contradiction and combination of opposites: artistic and scientific, "rigor and freedom", "oldfashionedness and modernity". An in-depth analysis of the nature of the genre in the researcher's works explains the hypertest, the intertextuality of essays and rethinks the new realities of modern Ukrainian literature.

G. Klochek in the work "The Phenomenal Essays of Eugene Malaniuk: seven signs" notes: «слово «феноменальний» вжсиваємо в значенні надзвичайний, винятковий, рідкісний... I якщо це визначення застосовуємо щодо есеїстики, то таким чином немовби возводимо ї̈ до рівня видатного, нетлінного літературного явищуа, щуо піднесене до рівня класики, здатної витримати випробування часом. I, як явище, приналежне до класичного літературного фонду, воно потребує постійних пізнавальних зусиль - не тільки сьогодні, а ци завтра, $і$ післязавтра...» [5]. The researcher outlines the place and role of essays in the literary process, using the word "phenomenal", identifying it with classical literature, but emphasizing the need for a constant process of cognition of the literary phenomenon, constant search and discovery, knowledge of essays not only as a literary phenomenon, but as the integrity of deep meanings.

M. Balaklytsky in work "Essays as an Artistic and Journalistic Genre..." refers to Ukrainian essays and notes, that it is "відзначається романтичним підходом, оптимізмом при висвітленні трагічних явищ, української історї, посиленим історичним дискурсом, спрямованістю на пробудження української національної свідомості з редукуванням авторського «я» на користь глобальних проблем національної icmopiï» [1, c. 27]. This is mainly due to the fact that the Ukrainian typology of essays provides examples of mixed genre formations, focusing on autonomous artistic reality, which is a reflection of the thinking of the deep individual "I" of the artist, realized through the prism of perception.

Conclusions and prospects for further research. Evidently, it is quite obvious that the modern Ukrainian literary process is impossible to imagine without essays, which are fully represented in modern literature by numerous works, different in form, subject matter, issues and genres. The emergence of essays is rightly due to the needs of the recipient and the author himself, which are implemented in a unique, nonstandard form of communication. This unusual form has become a reflection of new experience on modern concepts of the world. In the literary process, among other genres and types of literary work, the essay occupies a prominent place, because being a work individualized, non-standard, unsystematic, but mature, captures the author's imagination and reader's need as cultural understanding and transition to a new era of Ukrainian literature.

Thus, the analysis of the works of modern theorists of essays allows us to represent this phenomenon as an exceptional component of the modern literary process, which requires a broader study and delineation of the concept as a stable cultural and artistic phenomenon. We must state that the growing interest in essays has led to an increasing of research attention to it. Given 
the works considered, it is important and promising to study in the future the interaction between the literary process and the development of essays, the artist and the concept of the work in the context of discursive practices, the reader and essay as a performative phenomenon in modern literature.

\section{REFERENCES:}

1. Балаклицький М.А. Есе як художньо-публіцистичний жанр : методичні матеріали для студентів зі спеціальності «Журналістика». Харків : ХНУ імені В.Н. Каразіна, 2007. 74 с.

2. Гнатюк О. Есей - це спосіб життя, у якому фуундаментом $€$ культура. 2018. URL: http://pen.org.ua/publications/esej-tse-sposib-zhyttyav-yakomu-fundamentom-ye-kultura-olya-gnatyuk/ (дата звернення: 13.06.2021).

3. Гром'як Р.Т. До вивчення джерел розвитку літературних видів і жанрів. Давнє і сучасне : вибрані статті $з$ літературознавства. Тернопіль : Лілея, 1997. С. 42-45.

4. Гук О. Становлення ідентичності жанру есе: методологічний аспект. Молодий вчений. 2018. № 9(61). С. 35-39.

5. Клочек Г.Д. Феноменальність есеїстики Євгена Маланюка: сім ознак. Палисадник. 2019. URL: http:// palisadnik.org.ua/text/fenomenalnist-eseyistiki-ievgena-malanyuka-simoznak (дата звернення: 11.06.2021).

6. Осадча Ю.В. Есеїстичне та романічне письмо як способи «мислити» літературу. Слово і Час. 2006. № 2. C. $29-38$

7. Сільман К.В. Есеїстика як перехідне жанрове утворення: теоретичний аспект. Наукові праці Чорноморського державного університету імені Петра Могили комплексу «Києво-Могилянська академія». 2017. Т. 301. Вип. 289. С. 137-143.

8. Швець Г.Д. Есеїстика Василя Барки: жанрова специфріка та проблематика : авторефр. дис. ... канд. філол. наук : 10.01.01. Київ, 2006. 20 с.

9. Шебеліст С.В. Особливості розвитку сучасної української есеїстики в системі журналістських жанрів : дис. ... канд. наук із соц. комун. : 27.00.04. Київ, 2009. 187 с.

10. Шевченко Т.М. Есе як дискурсивна практика: до постановки проблеми. Срібний вік: діалог культур : збірн. наук. статей за матер. IV міжнародн. наук. конференції, присвяч. пам'яті проф. С.П. Ільйова. Одеса : Астропринт, 2018. С. 290-303.

11. Шевченко Т.М. Есеїстика українських письменників як френомен літератури кінця XX - початку XXI ст. : монографія. Київ : Видавничий дім Дмитра Бураго, 2019. 584 с.

УДК 821.161.2-1.09:17.035.3]Шевченко Т.

DOI https://doi.org/10.32782/tps2663-4880/2021.17-2.31

\section{МОТИВ ІСТОРИЧНОЇ СПАДКОСМНОСТІ НАЦІЇ В ПОЕЗІЯХ Т. ШЕВЧЕНКА 1837-1850 РОКІВ}

\section{THE MOTIF OF THE HISTORICAL SUCCESSION OF THE NATION IN THE POEMS OF TARAS SHEVCHENKO OF 1837-1850}

Гудима А.О. orcid.org/0000-0003-2081-0791 кандидат філологічних наук, асистент кафедри історії украӥнської літератури, теорії літератури і літературної творчості Київського начіонального університету імені Тараса Шевченка

Аналізуючи мотив історичної спадкоємності нації в поезіях Т. Шевченка 1837-1850рр. (трьох перших періодів творчості), звертаємося до питання Шевченкової національної самосвідомості, проблеми національної самосвідомості українців у різні історичні періоди, зумовленої несприятливими зовнішньополітичними умовами та складною внутрішньою ситуацією, ролі козацької спадщини та питання спадкоємності поколінь українців в опорних для нації досягненнях, досвіді боротьби за національну державу та невдач (стосовно української еліти).

Зокрема, з'ясовуємо загальні принципи зображення поетом козаків як типових представників української минувшини, роль козацтва в історії; також визначаємо загальні принципи зображення автором «людей» як збірного образу, що постають типовими представниками сучасного Т. Шевченкові підімперського періоду. Не тільки в аспекті суспільних взаємин, але, головним чином, у контакті з історією, козацькою минувшиною. При цьому Т. Шевченко, констатуючи роз'єднаність українців - у цінностях, у ставленні до життя, у його смисловому наповненні, - послуговується схемою родинних зв'язків: діди - батьки - діти - онуки в різних варіаціях, у такий спосіб, підтримуючи ідею роду. 